\title{
Population, diversity and characteristics of cellulolytic microorganisms from the Indo-Burma Biodiversity hotspot
}

\author{
Sailendra Goyari ${ }^{1}$, Shantibala S Devi ${ }^{1}$, Mohan C Kalita ${ }^{2}$ and Narayan C Talukdar ${ }^{*}$
}

\begin{abstract}
Forest ecosystem harbour a large number of biotic components where cellulolytic microorganisms participate actively in the biotransformation of dead and decaying organic matter and soil nutrient cycling. This study explores the aerobic culturable cellulolytic microorganisms in the forest soils of North East India. Soil samples rich in dead and decaying organic matter were collected from eight conserved forests during the season when microbes were found to be most active. Cellulolytic microorganisms were isolated using selective media in which cellulose was the sole carbon source. Population of culturable, aerobic, cellulolytic microorganisms were found to be higher at the incubation temperature that corresponds to the natural ambient temperature of the site of sample collection. Bacterial population was higher in all of the sites than fungal population. Bacterial population ranged from $1.91 \times 10^{5}$ to $3.35 \times 10^{6} \mathrm{CFU} \mathrm{g}^{-1}$ dry soil while actinomycetes and fungal population ranged from $9.13 \times 10^{2}$ to $3.46 \times 10^{4} \mathrm{CFU} \mathrm{g}^{-1}$ dry soil and $9.36 \times 10^{2}$ to $4.31 \times 10^{4}$ CFU g ${ }^{-1}$ dry soil, respectively. It was observed that though many isolates showed activity on the CMC plate assay, very few isolates showed significant filter paper activity. Three cellulolytic fungal isolates showing high FPase activity were characterised, identified and submitted to GenBank as Talaromyces verruculosus SGMNPf3 (KC937053), Trichoderma gamsii SGSPf7 (KC937055) and Trichoderma atroviride SGBMf4 (KC937054).
\end{abstract}

Keywords: Microbial population; Cellulolytic microorganisms; Forest soil; CMC plate assay; FPase activity

\section{Introduction}

In recent years, due to uncertainty in fossil fuel price and concerns over climate change, there is a global urge in reducing the use of fossil fuels and cut down greenhouse gas emission. This calls for generation of clean and sustainable energy alternatives. The noble idea of utilizing the biological process to convert cheap and abundant cellulosic biomass to fuels and chemicals offers one of the best choices (Bayer 2009). As of now, microbial conversion is the main route for biomass based alternative fuel production (Alper et al. 2009). Many cellulose degrading microorganisms secrete cocktails of numerous lignocellulolytic enzymes viz. cellobiohydrolase $(\mathrm{CBH})$, endo-1, 4- $\beta$-D-glucanase (EG) and $\beta$-glucosidase (BG) which acts synergistically to degrade lignocellulosic biomass completely (Bisaria et al. 1981). However in the

\footnotetext{
* Correspondence: dir.iasst@nic.in

'Institute of Bioresources and Sustainable Development (IBSD), Imphal, India Full list of author information is available at the end of the article
}

perspective of lignocellulosic based bioethanol production, the costs of these enzymes are still very high (Olson et al. 2011; Klein et al. 2012). Circumventing the high cost of cellulase production remains the top priority in the field of cellulase research. Therefore, there has been much research aimed at obtaining new microorganisms producing cellulolytic enzymes with higher specific activities and greater efficiency (Johnvesly et al. 2002; Lee and Koo 2001; Pattana et al. 2000; Subramaniyan and Prema 2000).

Aerobic microorganisms use different strategies to degrade lignocellulose. They secrete enzymes with different cellulolytic activities. Forest floor and soil horizons harbour ecologically more diverse microbial populations which contribute substantially to decomposition and soil cycling in forest soils (Kellner et al. 2010). In forest ecosystem, cellulolytic fungi are largely responsible for breakdown of large biopolymers viz. cellulose, hemicellulose, lignin and chitin. Fungal cellulase systems consist 
of a number of exocellulases and endocellulases with different properties and functions in the hydrolysis of crystalline cellulose (Irwin et al. 2000). The ability of microorganisms to degrade cellulose varies not only due to its genetic potential but also due to different environmental conditions within the niche where it operates. North East India represents diverse ecological niches with its unique geography. It stands as the transitional zone between the Indian, Indo-Malayan and IndoChinese biogeographic regions and is the geographical gateway for much of India's flora and fauna (Myers et al. 2000). As a consequence, the area is one of the richest in biological values, high in endemism of biological systems and provides unique niches for the evolution of novel microorganisms. However, the region has remained poorly explored in this aspect. Here, we have attempted to study the population diversity of culturable cellulose degrading microorganisms and characterize efficient cellulolytic fungal isolates from the undisturbed forests of this region.

\section{Material and methods Sample collection}

Eight different conserved forest sites located in North East India with different geo-climatic conditions were chosen for sample collection (Table 1). Soil samples were collected from three decomposed organic rich spots of each site where each spot was about $100 \mathrm{ft}$ apart. The subsurface soils from the depth of $0-15 \mathrm{~cm}$ were collected in sterile sample containers, wrapped in sterile polythene bag and transported to the laboratory in cool boxes. The samples were then stored in the cold room at $4^{\circ} \mathrm{C}$ until further analysis.

\section{Isolation of cellulolytic microorganisms and population count}

Three selective media viz. Omeliansky's agar, Czapek Dox agar (CDA) and Kenknight and Munier's agar (K\&M) were prepared with slight modification for isolation of bacteria, fungi and actinomycetes, respectively. The carbon source in each of the selective media was substituted with cellulose powder $(3 \mathrm{~g} / \mathrm{L})$. Five gram of soil sample sieved through $2 \mathrm{~mm}$ pore sized sieve was mixed with $45 \mathrm{ml}$ of phosphate buffered saline (PBS). The solution suspension was agitated in a shaker incubator to release the microorganisms from the soil sample. Serial dilution was made in the same buffer. $100 \mu \mathrm{l}$ of each dilution was pour plated on the modified selective media. The plates were incubated at two temperature $\left(20^{\circ} \mathrm{C}\right.$ and $\left.30^{\circ} \mathrm{C}\right)$ for $3-7$ days. All colonies were counted and the bacterial populations were expressed as Colony Forming Unit (CFU) per gram sample dry weight. The population of culturable aerobic microorganisms were determined by plating three replicates of each dilution. Distinct colonies were picked and subcultured to get pure isolates.

\section{Screening for cellulase activity}

Three microliters of bacterial and actinomycetes cultures grown overnight in LB broth media (Himedia) were spot plated on CMC agar $\left(0.2 \% \mathrm{NaNO}_{3}, 0.1 \% \mathrm{~K}_{2} \mathrm{HPO}_{4}, 0.05 \%\right.$ $\mathrm{MgSO}_{4}, 0.05 \% \mathrm{KCl}, 0.2 \%$ carboxy methyl cellulose (CMC) sodium salt, $0.02 \%$ peptone, and $1.7 \%$ agar) (HiMedia, India). A mycelial disc ( $0.3 \mathrm{~cm}$ dia each) of fungal colony was placed on the centre of the modified Cezapak Dox Agar (CDA) plate supplemented with CMC instead of cellulose powder and $\mathrm{pH}$ adjusted to 5.3 for screening cellulolytic activity. The culture plates were incubated at $20^{\circ} \mathrm{C}$ and $30^{\circ} \mathrm{C}$. After 4 days of incubation, the culture plates were flooded with Gram's Iodine for 2-3 min (Kasana et al. 2008). Positive colonies were determined by the relative cellulolytic activity index (RCAI) which compares the diameter of the clearing zone around the colony with the diameter of microbial colony.

\section{Optimum $\mathrm{pH}$ and temperature on growth}

Modified CDA plate medium of $\mathrm{pH}$ gradient 3.3, 4.3, 5.3, 6.3, 7.3 and 8.3 adjusted with $10 \%$ Tartaric acid and $1 \mathrm{M} \mathrm{NaOH}$ were prepared. Each set of $\mathrm{pH}$ graded media plates were inoculated with one mycelia disc (each $0.3 \mathrm{~cm}$ dia) of SGMNPf3, SGBMf4 and SGSPf7 isolates and incubated at $30^{\circ} \mathrm{C}$ in stationary incubator for $60 \mathrm{hr}$.

Table 1 Geographical location of soil sample collection sites

\begin{tabular}{|c|c|c|c|c|}
\hline Name of state & Site of collection & Latitude & Longitude & Altitude (ft) \\
\hline \multirow[t]{2}{*}{ SIKKIM } & Tsomgo Lake Area & $\mathrm{N} 27^{\circ} 22.399$ & $\mathrm{E} 088^{\circ} 45.500$ & 12400 \\
\hline & Panthang & $\mathrm{N} 27^{\circ} 22.253$ & E088 35.288 & 6810 \\
\hline \multirow[t]{2}{*}{ MANIPUR } & Mao & $\mathrm{N} 25^{\circ} 31.883$ & $\mathrm{E} 094^{\circ} 07.946$ & 5680 \\
\hline & Moreh & $\mathrm{N} 24^{\circ} 15.345$ & E0941․ 316 & 800 \\
\hline ASSAM & Manas National Park & $\mathrm{N} 26^{\circ} 42.864$ & E090⒌ 5966 & 523 \\
\hline MEGHALAYA & Shillong Peak & $\mathrm{N} 25^{\circ} 32.539$ & E09152.285 & 6000 \\
\hline AURNACHAL & Namdapha National Park & $\mathrm{N} 27^{\circ} 29.737$ & $\mathrm{E} 096^{\circ} 23.393$ & 1100 \\
\hline PRADESH & Bomdila & N27º 16.343 & E092 25.344 & 8284 \\
\hline
\end{tabular}


The growth in diameter was measured every $12 \mathrm{hr}$ interval. Another set of media plates with $\mathrm{pH} 5.3$ were inoculated with a mycelia disc (each $0.3 \mathrm{~cm}$ dia) of the three isolates, each in triplicate and incubated at different temperature range $\left(15^{\circ} \mathrm{C}, 25^{\circ} \mathrm{C}, 30^{\circ} \mathrm{C}\right.$ and $\left.37^{\circ} \mathrm{C}\right)$.

\section{Optimum $\mathrm{pH}$ and temperature on enzyme production}

The effect of $\mathrm{pH}$ on enzyme production was analysed by varying the $\mathrm{pH}$ (3.3 to 8.3) of modified Czapek Dox Broth (CDB) medium supplemented with cellulose powder (3 g/L). Six mycelial discs, each of SGMNPf3, SGBMf4 and SGSPf7 isolates were inoculated in $30 \mathrm{ml}$ $\mathrm{CDB}$ medium contained in Erlenmeyer flask and incubated in an orbital shaker $(120 \mathrm{rpm})$ at $30^{\circ} \mathrm{C}$ for 8 days. Similarly, the effect of temperature was studied at $15^{\circ} \mathrm{C}$, $25^{\circ} \mathrm{C}, 30^{\circ} \mathrm{C}, 35^{\circ} \mathrm{C}, 40^{\circ} \mathrm{C}$ and $45^{\circ} \mathrm{C}$, keeping the $\mathrm{pH}$ of the culture medium at $\mathrm{pH} 5.3$.

\section{Enzymes assays}

\section{Filter paper assay}

Filter paper assay was determined by incubating $32 \mathrm{mg}$ of punched pieces of filter paper in $1 \mathrm{ml}$ of $0.05 \mathrm{M}$ Sodium citrate buffer ( $\mathrm{pH} 4.8$ ) with $1 \mathrm{ml}$ of culture supernatant in $50 \mathrm{ml}$ capacity centrifuge tube at $50^{\circ} \mathrm{C}$. After $1 \mathrm{hr}, 3 \mathrm{ml}$ of Dinitrosalicylic acid (DNS) reagent was added and kept in boiling water bath for $5 \mathrm{~min}$. To stop the reaction, it was kept on ice for $5 \mathrm{~min}$ and then $1 \mathrm{ml}$ of $40 \%$ Rochelle salt solution was added. A Blank, without filter paper was also run to correct for any reducing sugar present in the enzyme preparation (Eveleigh et al. 2009). One Filter Paper Unit (FPU) was defined as the amount of the enzyme that released $1 \mu$ mole of glucose per minute from the original substrate at the experimental conditions.

\section{Individual cellulase assays}

Endoglucanase and $\beta$-glucosidase activity assay were carried out by following the protocol of Thygesen et al. (2003). For exoglucanase activity, it was measured by using 1\% Avicel (Sigma Chemical, St. Louis, USA) in $100 \mathrm{mM}$ sodium acetate buffer ( $\mathrm{pH} 4.8)$ as described by Wood and Bhat (1988). One unit (IU) of enzyme activity was defined as the amount of the enzyme that released 1 $\mu$ mole of glucose per minute from the original substrate at the experimental conditions for the endoglucanase and exoglucanase activity assay. For $\beta$-glucosidase activity, one unit (IU) is defined as the amount of the enzyme that releases $1 \mu$ mole of $\mathrm{p}$ - Nitrophenol per minute from the $\mathrm{p}$-Nitrophenyl $\beta$-D-glucopyranoside.

\section{Protein precipitation}

The extracellular proteins from the culture supernatant were precipitated by $\left(\mathrm{NH}_{4}\right)_{2} \mathrm{SO}_{4}$ at $85 \%$ saturation. After standing overnight, the precipitate formed was collected by centrifugation at $10,000 \mathrm{~g}$ for $30 \mathrm{~min}$ (Thermo Scientific Biofuge Primo R) and then dissolved in $50 \mathrm{mM}$ sodium acetate buffer ( $\mathrm{pH}$ 5.3). The dissolved sample was dialyzed against the same buffer and concentrated by lyophilisation (Thermo Scientific).

\section{Extracellular protein profile}

Sodium Dodecylsulfate-Polyacrylamide Gel electrophoresis (SDS-PAGE) was performed according to the method of Laemmli (1970) using 12.5\% gels. After electrophoresis, the gels were stained by a solution of $0.1 \%(\mathrm{w} / \mathrm{v})$ Commassie blue, $40 \%(\mathrm{v} / \mathrm{v})$ methanol and 10\% (v/v) acetic acid. The gels were destained by a solution of $40 \%(\mathrm{v} / \mathrm{v})$ methanol and 10\% (v/v) acetic acid and then gels were kept in $7 \%$ (v/v) acetic acid. Molecular weight standards (Merck) were used to determine the molecular weight of the extracellular proteins.

\section{Genomic DNA isolation}

The SGMNPf3, SGBMf4 and SGSPf7 isolates were grown in $30 \mathrm{ml}$ potato-dextrose broth medium for $72 \mathrm{hr}$ at $30^{\circ} \mathrm{C}$. The mycelial mat was pelleted by centrifugation (Eppendorf Centrifuge R2050) at 3,000 rpm for $20 \mathrm{~min}$. Genomic DNA was isolated following the rapid extraction method for PCR amplification (Cenis 1992).

\section{Identification of three fungi}

For sequence analaysis of the ITS1-5.8S-ITS2 r DNA region, PCR was performed in a $\mathrm{C}_{1000^{\mathrm{Tn}}}$ Touch Thermal Cycler (BIORAD, USA) using the primer set: $5^{\prime}$-CTT GGTCATTTAGAGGAAGTAA-3' and 5'-TCCTCCGCT TATTGATATGC-3' according to standard protocol (White et al. 1990). The run was programmed with an initial denaturation at $95^{\circ} \mathrm{C}$ for $5 \mathrm{~min}$, followed by amplification for 34 cycles at the following conditions: $1 \mathrm{~min}$ at $95^{\circ} \mathrm{C}, 1 \mathrm{~min}$ at $50^{\circ} \mathrm{C}$ and $2 \mathrm{~min}$ at $72^{\circ} \mathrm{C}$. A final $5 \mathrm{~min}$ extension at $72^{\circ} \mathrm{C}$ and infinite hold time at $12^{\circ} \mathrm{C}$ completed the program run. The amplified products were profiled in $1.5 \%$ agarose gel and visualized with ethidium bromide in ChemiDoc $^{\text {Tw }}$ MP Imaging System (BIORAD, USA). Amplicons of about 450-580 bp were purified and sequenced in ABI370X1 Cycler Sequencer (ABI, USA). The sequences were automatically trimmed and assembled in DNAbaser 3.5.3 software. Following annotation, sequences were assigned to species based on 98-100\% sequences similarity threshold in the GenBank. The rDNA sequences of SGMNPf3, SGBMf4 and SGSPf7 were submitted to GenBank ${ }^{\circ}$ with Accession Numbers KC937053, KC937054 and KC937055, respectively.

\section{Statistical significance test}

All statistical significance tests were determined by Oneway ANOVA using StatPlus. ${ }^{*} \mathrm{P}<0.05$. 


\section{Result and discussion \\ Population count and diversity of cellulolytic microorganisms}

Populations of three groups of cellulolytic microorganisms were found to be different in different sites. For example, in the sites like Tsomgo Lake area, Panthang, Mao and Shillong Peak where summer temperature is always below $25^{\circ} \mathrm{C}$, the bacterial population ranged from $2.35 \times 10^{5}$ to $3.28 \times 10^{6} \mathrm{CFU} \mathrm{g}^{-1}$ dry soil and from $1.91 \times 10^{5}$ to $5.2 \times 10^{5} \mathrm{CFU} \mathrm{g}^{-1}$ dry soil at $20^{\circ} \mathrm{C}$ and $30^{\circ} \mathrm{C}$, respectively. In contrast, the bacterial population in the sites like Moreh, Manas National Park and Namdapha National Park, where summer temperature is always above $25^{\circ} \mathrm{C}$, ranged from $1.03 \times 10^{5}$ to $3.08 \times 10^{5} \mathrm{CFU} \mathrm{g}^{-1}$ dry soil and from $1.91 \times 10^{5}$ to $1.06 \times 10^{6} \mathrm{CFU} \mathrm{g}^{-1}$ dry soil at $20^{\circ} \mathrm{C}$ and $30^{\circ} \mathrm{C}$, respectively. Similar trend was observed for actinomycetes and fungal population (Table 2). In this study, more microbial colonies were obtained by incubating at the temperature similar to that of the sites from where the samples were collected. This suggests that cellulolytic microorganisms can flourish in culture medium only when they are incubated at their natural ambient environment and therefore, this should be an important consideration in culture based diversity study. It was also observed that the cellulolytic bacterial population was higher compared to actinomycetes and fungi in all of the sites. Among the three groups of microorganisms, fungal population was the lowest. This observation contradicts with many other reports that fungal population dominates bacteria in the forest site with decomposing litter (Baath and Anderson 2003; Baldrian et al. 2012). This contradiction might be due to total soil DNA approach used for estimation of the microbial diversity in their study. However, our results agreed with the report that the ratios of culturable bacteria to culturable fungi were greater in the forest soil, which was based on the classical plate media culturable approach (Matthies et al. 1997). A total of 212 microbial isolates were obtained from the soil samples using cellulose supplemented media (Table 3). The isolates were distinct from one another as evident from their purified colonies on the culture media (Figure 1). On comparison of the colony morphology of the isolates obtained from sample of different sites, it was found that the number of groups of dissimilar colonies was different for different sites. We treated colonies of different isolates obtained from a sample as more diverse, if it had more dissimilar groups of colonies compared to that of another sample. Accordingly, the bacterial diversity was highest in Namdapha National Park and lowest in Tsomgo Lake Area. The actinomycetes diversity was highest in Namdapha National Park and lowest in Tsomgo Lake Area and Manas National Park. Among the different sites, Shillong Peak and Namdapha National Park had more fungal diversity while Moreh had the lowest fungal diversity. It was observed that samples from Namdapha National Park had the highest diversity of the three groups of microorganisms. However, no conclusion could be drawn on the correlation of the diversity of different types of microorganisms and the different temperature regimes of sample sites.

Table 2 Population count of aerobic cellulolyitc microorganisms from different sites

\begin{tabular}{|c|c|c|c|c|c|}
\hline \multirow[t]{2}{*}{ Site } & \multirow{2}{*}{$\begin{array}{c}\text { Annual } \\
\text { temperature }\left({ }^{\circ} \mathrm{C}\right)\end{array}$} & \multirow{2}{*}{$\begin{array}{c}\text { Incubation } \\
\text { temperature }\left({ }^{\circ} \mathrm{C}\right)\end{array}$} & \multicolumn{3}{|c|}{ CFU/g dry soil } \\
\hline & & & Bacteria & Actinomycetes & Fungi \\
\hline \multirow[t]{2}{*}{ Tsomgo Lake Area } & Max. 10 & 30 & $2.10 \times 10^{5}$ & $8.10 \times 10^{3}$ & $2.13 \times 10^{3}$ \\
\hline & Min. 2 & 20 & $2.34 \times 10^{5}$ & $3.02 \times 10^{4}$ & $3.77 \times 10^{3}$ \\
\hline \multirow[t]{2}{*}{ Panthang } & Max. 22 & 30 & $8.40 \times 10^{5}$ & $9.13 \times 10^{2}$ & $9.36 \times 10^{2}$ \\
\hline & Min. 13 & 20 & $3.28 \times 10^{6}$ & $3.46 \times 10^{4}$ & $6.97 \times 10^{3}$ \\
\hline \multirow[t]{2}{*}{ Manas National Park } & Max. 37 & 30 & $1.91 \times 10^{5}$ & $3.06 \times 10^{3}$ & $3.51 \times 10^{3}$ \\
\hline & Min. 25 & 20 & $1.03 \times 10^{5}$ & $2.11 \times 10^{3}$ & $2.33 \times 10^{3}$ \\
\hline \multirow[t]{2}{*}{ Mao } & Max. 23 & 30 & $5.19 \times 10^{5}$ & $8.79 \times 10^{3}$ & $3.39 \times 10^{3}$ \\
\hline & Min. 14 & 20 & $4.17 \times 10^{5}$ & $1.61 \times 10^{4}$ & $1.72 \times 10^{4}$ \\
\hline \multirow[t]{2}{*}{ Moreh } & Max. 35 & 30 & $1.06 \times 10^{6}$ & $2.38 \times 10^{4}$ & $3.98 \times 10^{3}$ \\
\hline & Min. 25 & 20 & $3.08 \times 10^{5}$ & $2.82 \times 10^{3}$ & $1.69 \times 10^{3}$ \\
\hline \multirow[t]{2}{*}{ Namdapha National Park } & Max. 37 & 30 & $3.35 \times 10^{6}$ & $2.74 \times 10^{4}$ & $9.54 \times 10^{3}$ \\
\hline & Min. 30 & 20 & $2.39 \times 10^{6}$ & $2.20 \times 10^{4}$ & $4.31 \times 10^{4}$ \\
\hline \multirow[t]{2}{*}{ Bomdila } & Max. 26 & 30 & $5.2 \times 10^{5}$ & $8.8 \times 10^{3}$ & $9.06 \times 10^{3}$ \\
\hline & Min. 11 & 20 & $8.5 \times 10^{5}$ & $9.3 \times 10^{3}$ & $1.3 \times 10^{4}$ \\
\hline \multirow[t]{2}{*}{ Shillong Peak } & Max. 24 & 30 & $8.75 \times 10^{5}$ & $2.98 \times 10^{4}$ & $6.34 \times 10^{3}$ \\
\hline & Min. 2 & 20 & $5.84 \times 10^{5}$ & $2.15 \times 10^{4}$ & $1.07 \times 10^{4}$ \\
\hline
\end{tabular}


Table 3 Total number of aerobic cellulolytic microorganisms from soil

\begin{tabular}{lccc}
\hline Sample source & \multicolumn{3}{c}{ Total number of microorganisms } \\
\cline { 2 - 4 } & Bacteria & Actinomycetes & Fungi \\
\hline Tsomgo Lake Area & 7 & 2 & 6 \\
Panthang & 8 & 4 & 8 \\
Manas National Park & 8 & 2 & 7 \\
Mao & 8 & 4 & 6 \\
Moreh & 7 & 4 & 5 \\
Namdapha National Park & 14 & 25 & 12 \\
Bomdila & 12 & 13 & 11 \\
Shillong Peak & 13 & 14 & 12 \\
Total & 77 & 68 & 67 \\
\hline
\end{tabular}

\section{Qualitative and quantitative cellulase activity}

Of the 212 isolates, 168 showed CMC hydrolysis zone in the plate assay. The RCAI values of bacteria and actinomycetes ranged from 0.8 to $2.3 \mathrm{~cm}$ whereas for fungi, it ranged from 0.4 to $2.6 \mathrm{~cm}$. The FPase activity of bacteria and actinomycetes ranged from 0.3 to $8 \mathrm{FPU}$ whereas for fungi, it ranged from 2 to 44 FPU. It was observed that high RCAI index on CMC plate assay did not correspond to high FPase activity for bacteria and actinomycetes (Table 4). Dashtban et al. (2010) reported that Gram's iodine was superior test than others for a fast and easy detection of endoglucanase activity on $\mathrm{CMC}$ plate assay. Their results clearly indicated that those organisms which had less or no endoglucanase activity did not show the hydrolysis zone on the CMC plate assay. This might suggest that the bacterial and actinomycetes isolates did not produce the other cellulase enzymes whereas SGMNPf3 produced all and hence, showed positive in both the assays. Thus, it infers that CMC plate assay is not sufficient to conclude the cellulase producing potential of microorganisms.

\section{Identification of three fungal isolates}

Colonial morphology of SGBMf4 and SGSPf7 were spreading and white floccose mycelia. The mycelia of SGSPf7 were covered with greenish spores after 10 days of incubation while mycelia of SGBMf4 were observed to be covered with green spores in the centre and yellowish towards the margin. The elevation of mycelial colonies of SGMNPf3 were flat on the edge, slightly floccose at the centre and sporulation was indistinguishable. The ITS sequences of the three potential fungal isolates viz. SGMNPf3, SGBMf4 and SGSPf7 were submitted to GenBank with accession numbers- KC937053, KC937054 and KC937055, respectively. The isolate SGMNPf3 showed highest identity to Talaromyces verruculosus (99.1\%), SGBMf4 to Trichoderma atroviride (99.5\%) and SGSPf7 to Trichoderma gamsii (99.9\%) in the NCBI blast search. Phylogenetic relationships were drawn using alignment and cladistics analyses of homologous nucleotide sequences of known microorganisms (Figure 2). Based on their colonial morphology and comparisons of their ITS rDNA gene sequences, the isolated strains were identified and named as Talaromyces verruculosus SGMNPf3, Trichoderma atroviride SGBMf4 and Trichoderma gamsii SGSPf7.

\section{Growth and cellulase production parameters of three fungal isolates}

Temperature and $\mathrm{pH}$ are the important physiological parameters affecting the growth and enzyme production of microorganisms. In our study, optimum growth rate of

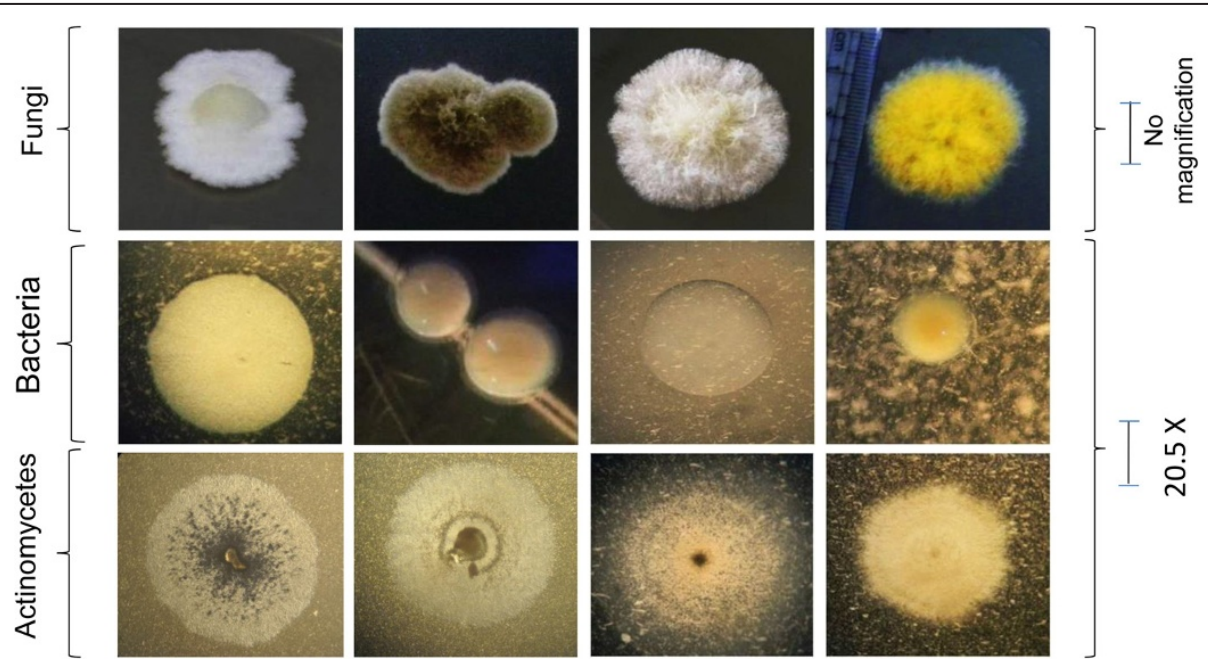

Figure 1 Colonial morphology of few cellulolytic microorganisms. Fungal colonies were photographed without any magnification using Nikon D-5000 camera. Bacteria and actinomycetes colonies were photographed using stero zoom microoscope (Olympus) at 20.5X magnification. 
Table 4 Comparative analysis on cellulolytic activities of different microbial isolates

\begin{tabular}{llll}
\hline Microorganism & Isolate code & RCAI (cm) & FPase (IU/L) \\
\hline Fungi & MHf2 & $1.5 \pm 0.02$ & $13 \pm 1.40$ \\
& MOf5 & $1.1 \pm 0.03$ & $4.5 \pm 0.13$ \\
& MNPf3 & $2.6 \pm 0.01$ & $44 \pm 2.30$ \\
& BMf4 & $1.6 \pm 0.03$ & $21 \pm 1.33$ \\
& SPf7 & $0.9 \pm 0.04$ & $30 \pm 2.11$ \\
Bacteria & Activity range & $0.4-2.6$ & $2-44$ \\
& MHb5 & $1.2 \pm 0.02$ & $1.8 \pm 0.20$ \\
& MOb1 & $1.4 \pm 0.03$ & $1.2 \pm 0.30$ \\
& MNPb5 & $2.0 \pm 0.05$ & $2.1 \pm 0.40$ \\
& NNPb11 & $0.8 \pm 0.02$ & $1.1 \pm 0.10$ \\
& SLb3 & $1.2 \pm 0.02$ & $1.5 \pm 0.60$ \\
& Activity range & $0.8-2$ & $0.4-2$ \\
& SPac10 & $2.3 \pm 0.08$ & $6.7 \pm 1.40$ \\
& NNPac3 & $2.1 \pm 0.04$ & $1.4 \pm 0.10$ \\
& MHac7 & $1.1 \pm 0.05$ & $4.1 \pm 0.30$ \\
& SLac1 & $1.6 \pm 0.01$ & $0.8 \pm 0.01$ \\
& MHac5 & $2.2 \pm 0.02$ & $8.1 \pm 2.11$ \\
Activity range & $0.8-2.3$ & $0.3-8$ \\
\hline & & &
\end{tabular}

T. atroviride SGBMf4, T. gamsii SGSPf7 and T. verruculosus SGMNPf3 were observed at $\mathrm{pH} 5.3,4.3$ and 3.3 (Figure $3 \mathrm{a}, \mathrm{b} \& \mathrm{c}$ ) and at temperature $25^{\circ} \mathrm{C}, 25^{\circ} \mathrm{C}$ and $30^{\circ} \mathrm{C}$ (Figure $3 \mathrm{~d}$, e \& f), respectively. This observation reflects well to the temperature condition of sample collection sites. T. atroviride SGBMf4 had higher growth rate and T. verruculosus SGMNPf3 was the slowest. The result agreed with the reports that Trichoderma spp were fast growing at $25-30^{\circ} \mathrm{C}$ (Gams and Biset 1998; Yu et al. 2014). It was observed that Trichoderma isolates did not grow above $30^{\circ} \mathrm{C}$ except $T$. verruculosus SGMNPf3, which was able to grow at $37^{\circ} \mathrm{C}$. The $\mathrm{pH}$ and temperature at which the growth of the three fungi were optimum, were also observed to be the favourable condition for maximum enzyme production. Highest cellulase production of SGSPf7 (25 U/L) was observed at $25^{\circ} \mathrm{C}$ and $\mathrm{pH} 4.3$ (Figure $4 \mathrm{a} \& \mathrm{~d}$ ), SGBMf4 at $25^{\circ} \mathrm{C}$ and $\mathrm{pH} 5.3$ (Figure $4 \mathrm{~b} \& \mathrm{e}$ ) and SGMNPf3 (40 IU/L) at $30^{\circ} \mathrm{C}$ and $\mathrm{pH} 3.3$ (Figure 4c \& f). Similar observations were also reported by Singh et al. (2014). Though SGMNPf3 was a slow grower, it surpassed the other isolates in cellulase production potential. The acidophilic characteristic of SGMNPf3 makes it a promising candidate for industrial purposes since most of the substrates are pre-treated with inorganic acids (Hahn-Hagerdal et al. 2006; Tavares et al. 2013).

\section{Individual cellulase activity}

The three fungal isolates viz. T. verruculosus SGMNPf3, T. gambii SGSPf7 and T. atroviride SGBMf4 showed all of the three individual cellulase activities (Figure 5). The endoglucanase activity was observed to be highest for SGMNPf3 (555.8 IU/mg) and SGBMf4 (358.9 IU/mg) whereas exoglucanase activity was found to be highest for SGSPf7 (419.3 IU/mg) in their individual cellulase assays. The $\beta$-glucosidase activity was very low for SGBMf4

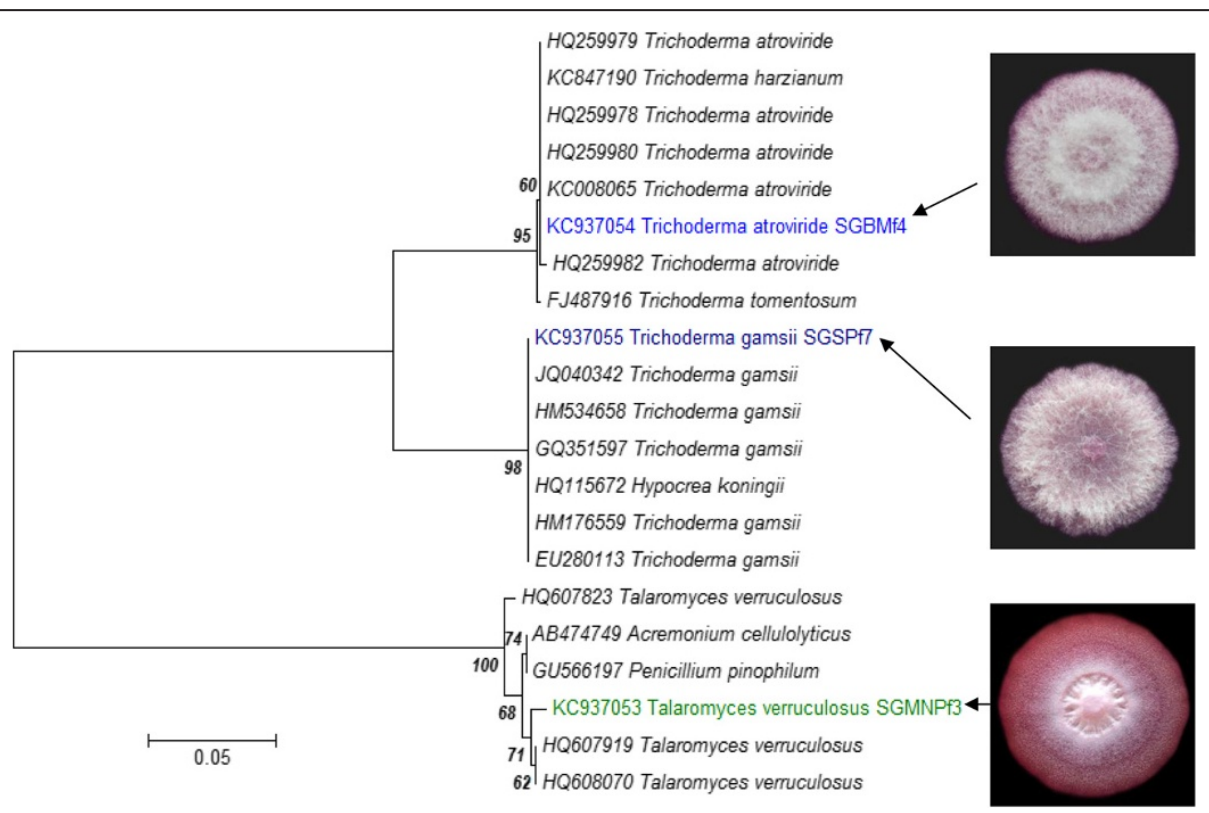

Figure 2 The phylogenetic dendrogram for T. atroviride SGBMf4, T. gamsii SGSPf7 and T. verruculosus SGMNPf3 and related strains based on the ITS rDNA sequence. Numbers following the names of the strains are accession numbers of published sequences. 


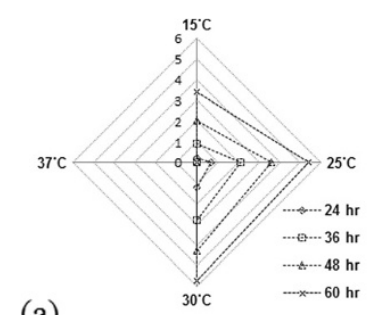

(a)

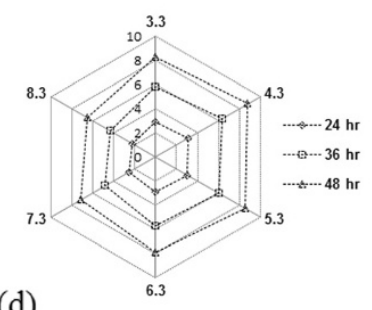

(d)

(e)

(b)
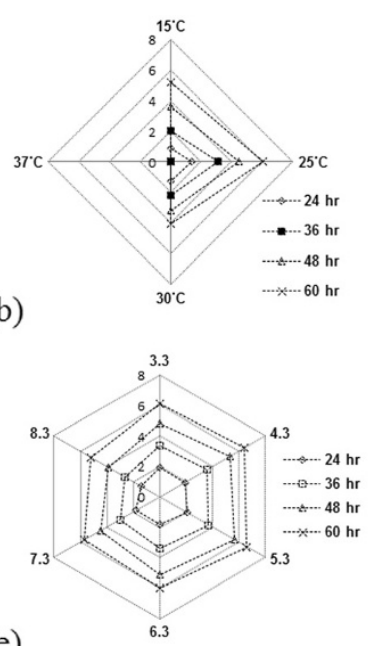

(f)
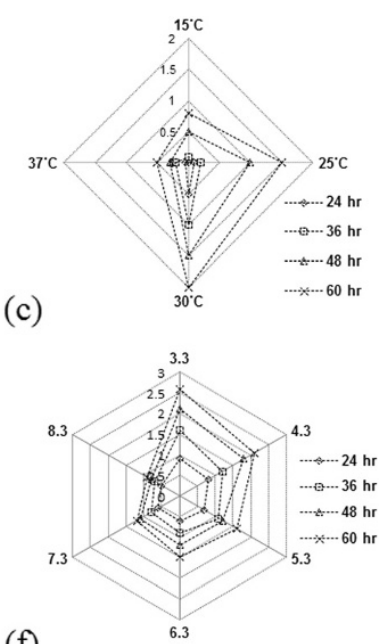

Figure 3 Growth pattern of fungal isolates at varying pH and temperature. Growth pattern of SGSPf7 at different pH (a) and temperature (d); Growth pattern of SGBMf4 at different pH (b) and temperature (e); Growth pattern of SGMNPf3 at different pH (c) and temperature (f).

(10.3 IU/mg) and SGSPf7 (14.1 IU/mg) whereas it was significantly high in SGMNPf3 (316.1 IU/mg). It has been reported that fungi belonging to genus Trichoderma, produce low amount of $\beta$-glucosidase (Gritzali and Brown 1979; Ma et al. 2011) while those that belong to genus Penicillium are good producers (van Wyk 1999; Castellanos et al. 1995; Jorgensen et al. 2005). This report strongly supports our observations. In this study, $T$. verruculosus SGMNPf3 showed higher individual cellulase activities compared to T. gambii SGBMf4 and T. atroviride SGSPf7. Though genus Trichoderma has been reported (HerpoelGimbert et al. 2008) to be high cellulase producer, Talaromyces which is a teleomorphic state of genus Penicillium had shown to be a better cellulase producer.

\section{Extracellular protein profile}

Understanding the different enzymes or protein secretions of microorganisms would unveil the mechanisms they adopts in the process of biomass degradation. The three fungal isolates revealed different extracellular protein secretions when grown on cellulose substrates. All the three fungi showed dominant extracellular protein bands which were in the molecular weight range of 60$75 \mathrm{kDa}$ (Figure 6). T. verruculosus SGMNPf3 and $T$. gamsii SGBMf4 showed two protein bands while T. atroviride SGSPf7 showed three protein bands which had molecular weight in the range of commercial cellulases (Sigma Aldrich) from Trichoderma reesei. A protein band of $36.5 \mathrm{kDa}$ was observed in the extracellular
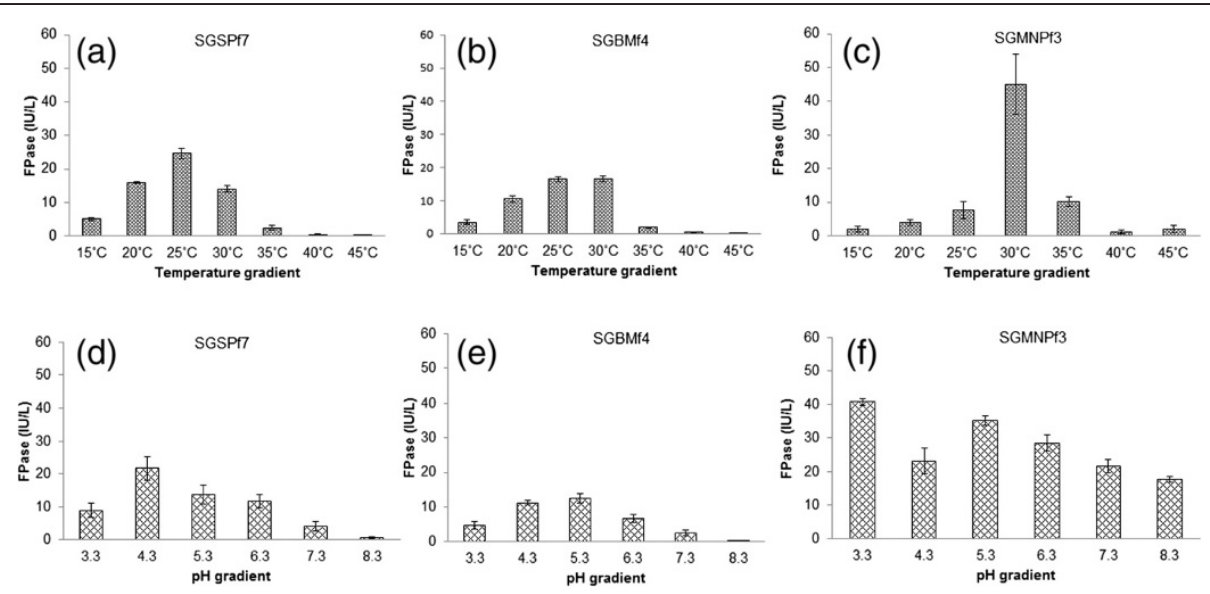

Figure 4 Cellulase production pattern of fungal isolates at varying $\mathrm{pH}$ and temperature. Pattern of SGSPf7 at different pH (a) and temperature (d); Pattern of SGBMf4 at different $\mathrm{pH}(\mathbf{b})$ and temperature (e); Pattern of SGMNPf3 at different pH (c) and temperature (f). 


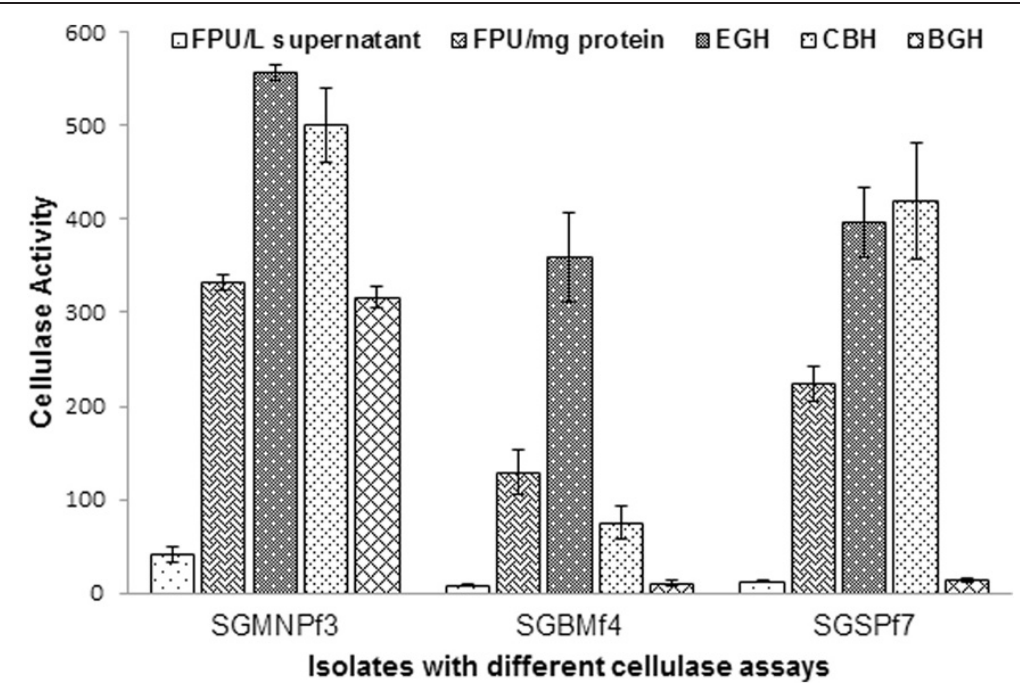

Figure 5 Individual cellulase production of three potential cellulolytic fungus.

protein sample of $T$. verruculosus SGMNPf3 which was not observed in the other isolates and commercial cellulase.

\section{Conclusion}

In the biomass degradation viewpoint, the population density of culturable cellulolytic bacteria was found to be higher compared to the fungi in the forest soil.
Microorganisms seems to thrive well in their native ambient $\mathrm{pH}$ and temperature. Although many microorganisms show cellulolytic activity, very few cellulolytic microorganisms have the potential to attract industrial application. Hence in this regard, cellulolytic potential of T. verruculosus SGMNPf3, T. gamsii SGSPf7 and T. atroviride SGBMf4 isolated from the Indo-Burma Biodiversity hotspot need to be further explored for activity of

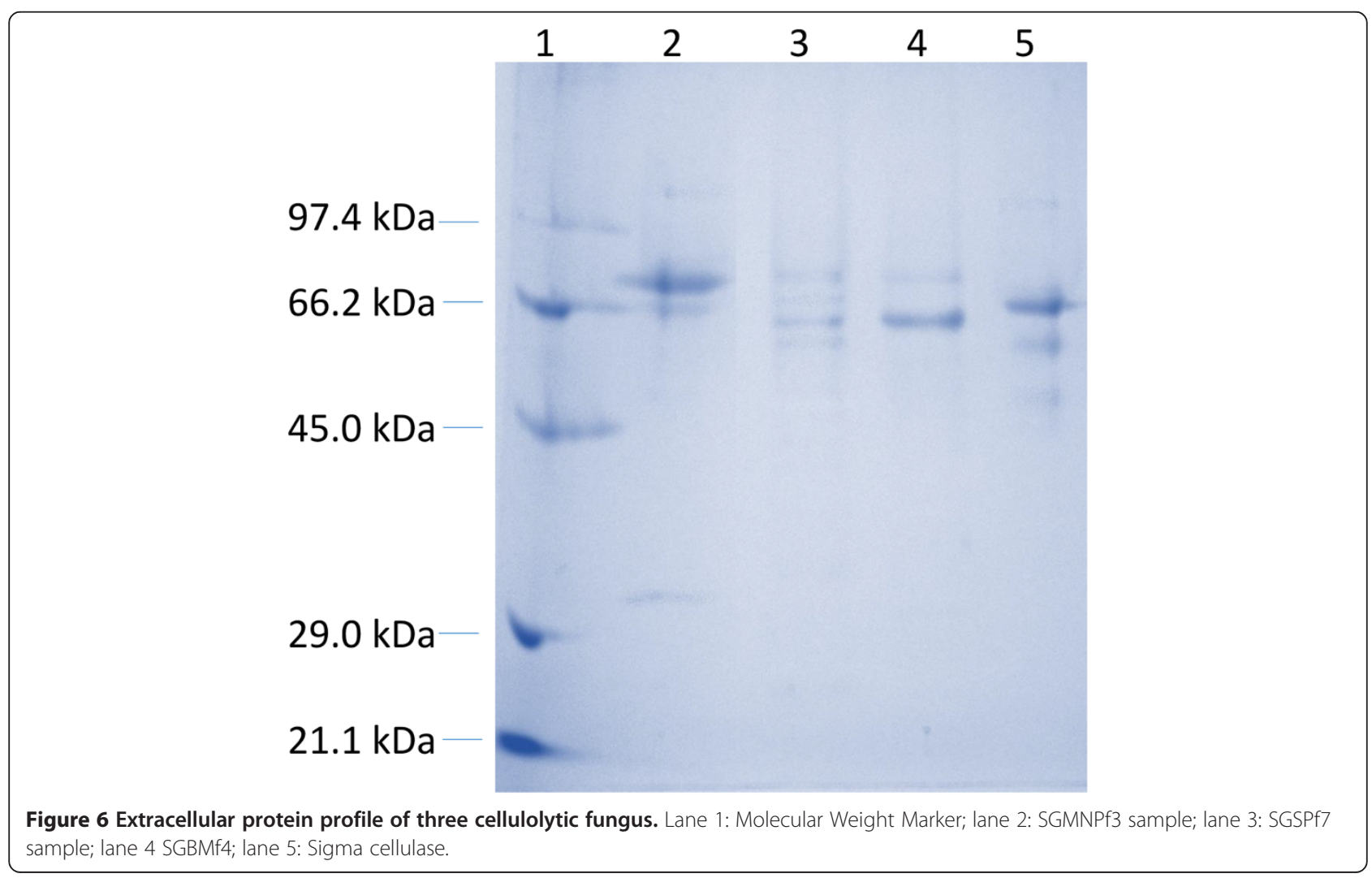


their purified cellulases and possible commercial scale cellulase production in future.

\section{Competing interest}

The authors declare that they have no competing interests.

\section{Authors' contributions}

SG carried out the experiment and wrote the manuscript; SSD assisted in microbial isolation. MCK assisted in drafting the manuscript. NCT conceived and supervised the experiment. All authors read and approved the final manuscript.

\section{Acknowledgement}

The authors acknowledge Department of Biotechnology, Government of India for the financial support in carrying out this work in the form of Junior Research Fellowship. The authors are very grateful to the Institute of Bioresources and Sustainable Development (IBSD), Imphal for providing the necessary laboratory facility.

\section{Author details}

${ }^{1}$ Institute of Bioresources and Sustainable Development (IBSD), Imphal, India. ${ }^{2}$ Gauhati University, Guwahati, India.

\section{Received: 24 July 2014 Accepted: 12 November 2014}

Published: 28 November 2014

\section{References}

Alper H, Stephanopoules G (2009) Engineering for biofuels: exploiting innate microbial capacity or importing biosynthetic potential? Nat Rev Microbiol 7:715-723

Baath E, Anderson TH (2003) Comparison of soil fungal/bacterial ratios in a pH gradient using physiological and PLFA-based techniques. Soil Biol Biochem 35:955-963

Baldrian P, Kolarik M, Stursova M, Kopecky J, Valaskova V, Vetrovsky T, Zifcakova L, Snajdr J, Ridl J, Vlcek C, Voriskova J (2012) Active and total microbial communities in forest soil are largely different and highly stratified during decomposition. ISME J 6:248-258

Bayer EA (2009) Remembering Mary (1917 to 2008): editorial introduction to the thematic series on the life and lifework of Mary Mandels, first lady of cellulase research. Biotechnol Biofuels 2:23

Bisaria VS, Ghose TK (1981) Biodegradation of cellulosic materials: substrates, microorganisms, enzyme and products. Enzyme Microb Technol 3:90-104

Castellanos OF, Sinitsyn AP, Vlasenko EY (1995) Comparative evaluation of hydrolytic efficiency toward microcrystalline cellulose of Penicillium and Trichoderma cellulases. Bioresour Technol 52:119-124

Cenis UL (1992) Rapid extraction of fungal DNA for PCR amplification. Nucleic Acids Res 20:9

Dashtban M, Maki M, Leung KT, Mao C, Qin W (2010) Cellulase activities in biomass conversion: measurement methods and comparison. Crit Rev Biotechnol 30(4):302-309

Eveleigh DE, Mandels M, Andreotti R, Roche C (2009) Measurement of saccharifying cellulase. Biotechnol Biofuels 2:2

Gams W, Biset J (1998) Morphology and identifcation of Trichoderma. In: Kubicek CP, Harman GE (ed) Trichoderma and Gliocladium. Taylor \& Francis, London; Bristol, PA, pp 3-31

Gritzali M, Brown RD, Jr (1979) The cellulase system of Trichoderma. In: Brown RD, Jr, Jurasek L (ed) Hydrolysis of Cellulose: Mechanisms of Enzymatic and Acid Catalysis. American Chemical Society, Washington, pp 237-260

Hahn-Hagerdal B, Galbe M, Gorwa-Grauslund MF, Liden G, Zacchi G (2006) Bio-ethanol-the fuel of tomorrow from the residues of today. Trends Biotechnol 24(12):549-556

Herpoel-Gimbert I, Margeot A, Dolla A, Jan G, Molle D, Lignon S, Mathis H, Sigoillot JC, Monot F, Asther M (2008) Comparative secretome analyses of two Trichoderma reesei RUT-C30 and CL847 hypersecretory strains. Biotechnol Biofuels 1:18. doi:10.1186/1754-6834-1-18

Irwin DC, Zhang S, Wilson DB (2000) Cloning, expression and characterization of a family 48 exocellulase, Cel48A, from Thermobifida fusca. Eur J Biochem 267:4988-4997

Johnvesly B, Virupakshi S, Patil GN, Naik GR (2002) Cellulase-free thermostable alkaline xylanase from thermophillic and alkalophillic Bacillus sp. JB-99. J Microbiol Biotechnol 12:153-156
Jorgensen H, Morkeberg A, Krogh KBR, Olsson L (2005) Production of cellulases and hemicellulases by three Penicillium species: effect of substrate and evaluation of cellulase adsorption by capillary electrophoresis. Enzyme Microb Technol 36:42-48

Kasana RC, Salwan R, Dhar H, Dutt S, Gulati A (2008) A rapid and easy method for the detection of microbial cellulases on agar plates using gram's iodine. Curr Microbiol 57:503-507

Kellner H, Vandenbol M (2010) Fungi unearthed: transcripts encoding lignocellulolytic and chitinolytic enzymes in forest soil. PLoS One 5(6):e10971

Klein MD, Oleskowicz PP, Simmons BA, Blanch HW (2012) The challenge of enzyme cost in the production of lignocellulosic biofuels. Biotechnol Bioeng 109:1083-1087

Laemmli UK (1970) Cleavage of structural proteins during the assembly of the head of bacteriophage T4. Nature 227:680-685

Lee SM, Koo YM (2001) Pilot-scale production of cellulose using Trichoderma reesei Rut C-30 in fed-batch mode. J Microbiol Biotechnol 11:229-233

Ma L, Zhang J, Zou G, Wang C, Zhou Z (2011) Improvement of cellulase activity in Trichoderma reesei by heterologous expression of a beta-glucosidase gene from Penicillium decumbens. Enzym Microb Technol 49:366-371

Matthies C, Erhard HP, Drake HL (1997) Effects of pH on the comparative culturability of fungi and bacteria from acidic and less acidic forest soils. J Basic Microbiol 37(5):335-343

Myers N, Mittermeier RA, Mitterermeier CG, da Fonseca GAB, Kents J (2000) Biodiversity hot spots for conservation prorities. Nature 403:853-858

Olson DG, McBride JE, Shaw JA, Lynd LR (2011) Recent progress in consolidated bioprocessing. Curr Opin Biotechnol 23:1-10

Pattana P, Khanok R, Khin LK (2000) Isolation and properties of a cellulosometype multienzyme complex of the thermophilic Bacteroidessp. strain P-1. Enzyme Microb Technol 26:459-465

Singh A, Shahid M, Srivastava M, Pandey S, Sharma A, Kumar V (2014) Optimal physical parameters for growth of Trichoderma species at varying $\mathrm{pH}$, temperature and agitation. Virol Mycol 3:1

Subramaniyan S, Prema P (2000) Cellulase-free xylanases from Bacillus and other microorganisms. FEMS Microbiol Lett 183:1-7

Tavares EQP, Rubini MR, Mello-de-Sousa TM, Duarte GC, Faria FP, Filho EXF, Kyaw CM, Pereira IS, Fonseca MJP (2013) An acidic thermostable recombinant Aspergillus nidulans endoglucanase is active towards distinct agriculture residues. Enzyme Res 2013:287343

Thygesen A, Thomsen AB, Schmidt AS, Jorgensen H, Ahring BK, Olsson L (2003) Production of cellulose and hemicellulose-degrading enzymes by filamentous fungi cultivated on wet-oxidised wheat straw. Enzym Microb Technol 32(5):606-615

Van Wyk JPH (1999) Hydrolysis of pre-treated paper materials by different concentrations of cellulase from Penicillium funiculosum. Bioresour Technol 69:269-273

White TJ, Bruns T, Lee S (1990) Amplification and direct sequencing of fungal ribosomal RNA genes for phylogenetics. In: Innis MA, Gelfand DH, Sninsky JJ, White TJ (ed) PCR Protocols: a Guide to Methods and Applications. Academic, New York, pp 315-322

Wood TM, Bhat KM (1988) Methods for measuring cellulase activities. Methods Enzymol 160:87-117

Yu C, Fan L, Wu Q, Fu K, Gao S, Wang M, Gao J, Li Y, Chen J (2014) Biological role of Trichoderma harzianum-derived platelet-activating factor acetylhydrolase (PAF-AH) on stress response and antagonism. PLoS One 9(6):e100367

\section{doi:10.1186/2193-1801-3-700}

Cite this article as: Goyari et al:: Population, diversity and characteristics of cellulolytic microorganisms from the Indo-Burma Biodiversity hotspot. SpringerPlus 2014 3:700. 